\title{
THE RELATION BETWEEN SUCROSURIA, HIATUS HERNIA AND MENTAL DEFECT
}

\author{
BY \\ S. FREIER* \\ From the Department of Child Health, University of Liverpool, and Alder Hey Children's Hospital, Liverpool
}

(RECEIVED FOR PUBLICATION JULY 10, 1961)

Sucrose or cane sugar is not a reducing substance and hence does not give a positive reaction with Benedict's solution. Its presence in the urine is, therefore, not detected on routine examination, and there are relatively few reports of sucrosuria in the literature. Worm-Müller (1884) reported the presence of cane sugar in the urine in normal individuals who had ingested sucrose in unusual quantity. This was confirmed by Le Goff (1911) who administered $100 \mathrm{~g}$. sugar to adults, all of whom developed temporary sucrosuria. Sucrosuria has been reported in children both in health as well as in those suffering from gastro-intestinal disturbances (Lahdensuu, 1947; Reuss, 1910; Owen and Lewis, 1956; Haworth, 1960). Sucrosuria has always been assumed to be secondary to the intake of sucrose with the exception of the cases reported by Elmer, Krasowska and Ptaszek (1939) and by Hoesch (1934). In these cases cane sugar was considered to be synthesized in the body.

The methods used in detecting sucrose have varied. Both the polariscope as well as chemical methods have been employed. Latterly, urine chromatography has been the method of choice. Moreover, while some have given a measured loading dose before testing the urine, others have relied on the sugar present in the diet.

In the past few years a number of conditions have been discovered in which mental retardation is associated with errors of metabolism manifesting themselves by the presence in the urine of unusual constituents. Examination of the urine by chromatographic methods has, therefore, become an important investigation in mentally retarded children. Moncrieff and Wilkinson (1954) described a group of mentally retarded children who had sucrosuria and, in addition, hiatus hernia. In the investigation of children with hiatus hernia, who were mentally normal, they found no sucrose. They suggested, therefore, that the triad sucrosuria, hiatus hernia

\footnotetext{
* Present address: Shaare Zedek Hospital, Jerusalem, Israel.
}

and mental defect constitutes a clinical syndrome. A further series of cases of the 'triad' sucrosuria, hiatus hernia and mental defect was reported from the same hospital by Woodruff (1958). Perry, Lippman, Walker and Shaw (1959) examined the urines of mentally normal and abnormal individuals, without hiatus hernia, and found that many of them passed sucrose in their urine if given a loading dose. As a result of this paper Moncrieff (1960) has altered his views. 'The biochemical aspects of sucrosuria are full of interest, and while I do not accept the view of Perry et al. that our cases are physiological variations, the conclusion that sucrosuria is unrelated causally to mental defect can be endorsed.' In the investigations recorded here, we came to the conclusion that sucrosuria is certainly a common finding in normal individuals. It was, however, more common in children who were suffering from hiatus hernia, but who were mentally normal. Furthermore, there is evidence to show that hiatus hernia is more common in mentally retarded children. There is, therefore, a tendency for the three conditions, hiatus hernia, mental defect and sucrosuria to occur together, although they are not causally related. It is our conclusion that the association of these three conditions, though not a syndrome, is not entirely a chance finding.

\section{Material and Methods}

The bladder was emptied and $20 \mathrm{~g}$. sucrose were given with the first meal of the day (except where otherwise stated). A normal diet was then given but without the addition of sucrose. All the urine passed for six hours was collected, and whenever possible it was obtained in three separate specimens at intervals of two hours. The sugars were identified by one-dimensional paper chromatography, and their concentration was roughly estimated by comparison with known amounts of the various sugars. An effort was made to measure the total quantity whenever possible, as the concentration alone may give a misleading interpretation.

Four groups were investigated: 1. Three patients 
TABLE 1

CLINICAL DATA ON CHILDREN WITH HIATUS HERNIA

\begin{tabular}{|c|c|c|c|c|c|c|}
\hline $\begin{array}{l}\text { Case } \\
\text { No. }\end{array}$ & Age & $\begin{array}{l}\text { Time of Onset } \\
\text { of Vomiting }\end{array}$ & $\begin{array}{l}\text { Radiological } \\
\text { Confirmation }\end{array}$ & $\begin{array}{l}\text { Operation for } \\
\text { Hiatus Hernia }\end{array}$ & & Comment \\
\hline $\begin{array}{r}1 \\
2 \\
3 \\
4 \\
5 \\
6 \\
7 \\
8 \\
9 \\
10 \\
11\end{array}$ & $\begin{array}{l}11 \mathrm{yrs} \\
4 \mathrm{mths} \\
5 \mathrm{yrs} \\
4 \mathrm{mths} \\
1 \frac{1}{2} \mathrm{yrs} \\
11 \mathrm{yrs} \\
5 \mathrm{yrs} \\
3 \mathrm{mths} \\
3 \mathrm{yrs} \\
3 \mathrm{yrs} \\
9 \mathrm{yrs}\end{array}$ & $\begin{array}{l}\text { Infancy } \\
\text { Shortly after birth } \\
\text { Shortly after birth } \\
4 \text { weeks } \\
2 \text { weeks } \\
\text { Birth } \\
\text { Infancy } \\
\text { Birth } \\
\text { Birth } \\
\text { Birth } \\
\text { Shortly after birth }\end{array}$ & $\begin{array}{l}\text { Yes } \\
\text { Yes } \\
\text { Yes } \\
\text { Yes } \\
\text { Yes } \\
\text { Yes } \\
\text { Yes } \\
\text { Yes } \\
\text { Yes } \\
\text { Yes } \\
\text { Yes }\end{array}$ & $\begin{array}{l}\text { Yes } \\
\text { No } \\
\text { Yes } \\
\text { No } \\
\text { No } \\
\text { Yes } \\
\text { No } \\
\text { No } \\
\text { Yes } \\
\text { Yes } \\
\text { No }\end{array}$ & \} & $\begin{array}{c}\text { Also had pyloric } \\
\text { stenosis } \\
\text { (see text) }\end{array}$ \\
\hline
\end{tabular}

showing hiatus hernia and mental defect; 2. Eleven mentally normal patients with hiatus hernia; 3.41 relatives of these two groups; 4. 38 normal controls.

Group 1. There were three cases with hiatus hernia who were mentally defective. The case reports are given in the Appendix.

Group 2. This consisted of 11 mentally normal patients with hiatus hernia (Table 1). The diagnosis was confirmed radiologically in all and at operation in five. Cases 4 and 5 were two sisters both of whom had pyloric stenosis in infancy which was confirmed at operation, as well as hiatus hernia demonstrated radiologically later on. They have a brother, not included in this series, who suffered from the same two conditions.

Group 3. This group consisted of the relatives of patients who had hiatus hernia, both with and without mental defect. The relatives usually comprised the parents and siblings and occasionally uncles, aunts and cousins of patients. One definite case and one doubtful case of hiatus hernia were found among them. There were no relatives who were mentally defective.

Group 4. Medical students volunteered to act as controls. In addition, children in surgical and ortho-

TABLE 2

ANALYSIS OF RESULTS

\begin{tabular}{|c|c|c|c|}
\hline & Total & $\begin{array}{l}\text { Sucrose } \\
\text { Present }\end{array}$ & $\begin{array}{l}\text { Per Cent. } \\
\text { With } \\
\text { Sucrosuria }\end{array}$ \\
\hline $\begin{array}{l}\text { Group } 1 \\
\text { Patients with hiatus hernia } \\
\text { and mental deficiency }\end{array}$ & 3 & 3 & 100 \\
\hline $\begin{array}{l}\text { Group } 2 \\
\quad \text { Hiatus hernia, but mentally } \\
\text { normal } \\
.\end{array}$ & 11 & 9 & 82 \\
\hline $\begin{array}{l}\text { Group } 3 \\
\quad \text { Relatives of patients } \\
\quad \text { hiatus hernia } \quad \ldots\end{array}$ & 41 & 18 & 44 \\
\hline $\begin{array}{lll}\text { Group } 4 & & \\
\text { Normal controls: } & \\
\text { Adults } & \ldots & \ldots \\
\text { Children } & . & \ldots\end{array}$ & $\left.\begin{array}{l}20 \\
18\end{array}\right\}^{38}$ & $\begin{array}{l}6 \\
7\end{array}$ & 34 \\
\hline
\end{tabular}

paedic wards served as controls. These included children admitted for 'cold' operations but not yet operated on, and cases of Perthes' disease. No child had a general anaesthetic less than one week before the test.

\section{Results}

Table 2 summarizes the results in all the patients. Of the three cases who were mentally retarded and who had hiatus hernia, all showed sucrosuria at some time. Of 11 mentally normal children who were suffering from hiatus hernia (Group 2) nine showed sucrose in the urine after a loading dose. Among 41 relatives of patients with hiatus hernia (with and without mental defect) only 18 showed sucrosuria. Of the 38 controls only 13 showed sucrosuria after a loading dose. This figure is in accord with the findings of Haworth (1960). He reports that five out of 13 healthy babies and five out of 16 older children showed sucrosuria following the administration of a test dose. The incidence of sucrosuria in his series therefore is $31 \%$ as compared with $34 \%$ in ours.

The possibility that sucrose was being absorbed through the inflamed mucosa of the lower oesophagus in patients with hiatus hernia was then considered. One of the patients had a gastrostomy performed because he had a stricture of the oesophagus associated with his hiatus hernia. Sucrose, $10 \mathrm{~g}$., was given through the gastrostomy tube. Over the next six hours he passed $61 \mathrm{mg}$. of sucrose. After a second test he passed $18 \mathrm{mg}$., and a third test was negative.

Two of the three cases showing the complete 'triad' had blood glucose curves investigated after a test dose of sucrose. The amount of sucrose given for the test was double the weight of glucose that would have been given for a glucose tolerance curve.

Case S.F., in Group 1, body weight $5 \mathrm{~kg}$., was given $24 \mathrm{~g}$. of sucrose by stomach tube at $10 \mathrm{a} . \mathrm{m}$. The fasting level of blood glucose was $100 \mathrm{mg}$.; blood glucose at 
10.30 a.m. was $145 \mathrm{mg}$; at 11 a.m. $125 \mathrm{mg}$.; at 12 noon $105 \mathrm{mg}$.; at 1 p.m. $90 \mathrm{mg}$; at 2 p.m. $95 \mathrm{mg}$.; and at 2.30 p.m. $90 \mathrm{mg}$.

Case S.S., also in Group 1, body weight $5 \mathrm{~kg}$., was given $24 \mathrm{mg}$. of sucrose orally at 9.35 a.m. The fasting level of blood glucose was $60 \mathrm{mg}$; blood glucose at 10.05 a.m. was $65 \mathrm{mg}$; at 10.35 a.m. $150 \mathrm{mg}$.; at 11.05 a.m. $130 \mathrm{mg}$.; and at 11.35 a.m. $80 \mathrm{mg}$.

These results show that sucrose was rapidly absorbed.

\section{Discussion}

Our results indicate that sucrosuria is not a rare finding even among normal people who have taken no more sugar than might be added to a cup of tea. The figures do, however, indicate that sucrosuria is commoner among children having abnormalities at the lower end of the oesophagus. The incidence of sucrosuria among the latter is more than double that of normal people. Statistically the result is significant at the $0.1 \%$ level. What possible connexion there may be between hiatus hernia and sucrosuria is not known. It has been suggested that the permeability of the alimentary tract is increased at the site of the oesophagus and that this allows the passage of unsplit sugar, but this cannot always be the case as our experiment showed.

As sucrosuria is not uncommon among normal people it does not seem likely that it is causally related to mental defect. One cannot draw an analogy between sucrose and galactose, the only one of the sugars which is known to be associated with mental defect. Galactose is normally metabolized within the body. When the appropriate enzymes are absent, galactose accumulates in the body and appears in the urine. On the other hand, once sucrose has gained access to the human body without undergoing previous hydrolysis to its constituent hexoses it is entirely and rapidly excreted in the urine. There seems to be no enzyme in the body with the exception of the digestive juice, capable of digesting this sugar (Peters and Van Slyke, 1946).

That there may be some connexion between hiatus hernia and mental defect is suggested by the report of Bonham-Carter (1956) who found six mentally defective children among 136 with hiatus hernia. Again, it does not seem that there is a specific syndrome of mental defect and hiatus hernia, but rather that mental defect from various causes predisposes to hiatus hernia.

In the literature there are conflicting reports of the occurrence of sucrosuria in various disorders. This seems to be due in part to the absence of any standard test comparable to a glucose tolerance test. The initial dose of sugar, the method of detecting it in the urine and, finally, the way of expressing the results vary from paper to paper, and it is to be hoped that some more uniform method will be adopted.

The following conclusion may be drawn. Sucrosuria is not a sufficiently specific finding for it to be regarded as an exclusive feature of any syndrome. There exists, however, an association between hiatus hernia and mental defect, and evidence is here presented that there is an increased incidence of sucrosuria in hiatus hernia. There may, therefore, be an unusually frequent association of these three features, but they do not form a specific syndrome.

\section{Summary}

One-third of normal individuals excrete sucrose in their urine after taking $20 \mathrm{~g}$. of the sugar.

Of children with hiatus hernia, over three-quarters have sucrosuria in similar circumstances. There is probably an association between hiatus hernia and mental defect. The three clinical findings, sucrosuria, hiatus hernia and mental defect may therefore be frequently found together, but they do not constitute a disease entity.

I am grateful to Professor John Hay for permission to publish, and to Drs. R. W. Brookfields, Saul Keidan and Hillel Blondheim for giving freely of their advice and criticism. I wish to acknowledge my debt to $\mathrm{Mr}$. Ireland and his department for the chemical estimations and to Miss P. Weiskopf for the statistical analysis.

\section{REFERENCES}

Bonham-Carter, R. E. (1956). In a discussion on unusual aspects of oesophageal disease. Proc. roy. Soc. Med., 49, 543.

Elmer, A. W., Krasowska, M. and Ptaszek, L. (1939). Sucrosuria: a rare metabolic error. Acta med. scand., 101, 596.

Haworth, J. C. (1960). Sugars in the blood and urine of children following the ingestion of disaccharides. Arch. Dis. Childh., 35,552 .

Hoesch, K. (1934). Spontane periodische Rohrzuckerausscheidung. Klin. Wschr 13, 275

Lahdensuu, S. (1947). On blood-sugar surves and saccharosuria in children due to saccharose tolerance test. Ann. Med. intern. Fenn., 36, 293.

Le Goff, J. (1911). Glycosurie et saccharosurie chez l'homme sain consécutives à l'absorption de 100 grammes de saccharose. C.R. Acad. Sci. (Paris), 152, 1785.

Moncrieff, A. (1960). Biochemistry of mental defect. Lancet, $2,273$.

- and Wilkinson, R. H. (1954). Sucrosuria with mental defect and hiatus hernia. Acta Paediat. (Uppsala), 43, Suppl. 100, p. 495 .

Owen, J. A. and Lewis, I. C. (1956). Sucrosuria in children. Scot. med. J., 1,231 .

Perry, T. L., Lippman, R. W., Walker, D. and Shaw, K. N. F. (1959). Sucrosuria and mental deficiency-a coincidence. Pediatrics, 24, 774.

Peters, J. P. and Van Slyke, D. D. (1946). Quantitative Clinical Chemistry, Interpretations, 2nd ed., vol. 1, p. 106. Williams and Wilkins, Baltimore.

Reuss, A. von (1910). Ueber alimentäre Saccharosurie bei darmkranken Säuglingen. Wien. klin. Wschr., 23, 123.

Woodruff, G. G. (1958). Sucrosuria in association with mental deficiency and hiatus hernia. J. Pediat., 52, 66.

Worm-Müller, B. (1884). Quoted by Utter, O. (1928). Über die Saccharosetoleranz und Saccharose-Ausscheidung im Harn bei Kindern. Acta Paediat. (Stockh.), 7, Suppl. 2, p. 71. 
Appendix

Case histories of the three patients having hiatus hernia, sucrosuria and mental defect.

Case 1. S.F., a male, was a second child. Pregnancy and delivery were uncomplicated. Vomiting started soon after birth. At the age of 6 weeks a barium swallow showed laxity at the cardio-oesophageal opening. At the age of 1 year he was unable to sit, had poor head control and took no interest in his surroundings. He had partial optic atrophy. The urine contained no phenyl-pyruvic acid and the Wassermann reaction was negative. Sucrosuria was first noticed at the age of 11 months. It is of interest to note that a paternal aunt had suffered from cardiospasm from the age of 7 years.

Case 2. S.S., a male, was a first child. Pregnancy was normal but delivery was complicated by uterine inertia. He was delivered by the breech with forceps to the after-coming head. He had micrognathus and cleft palate and was subject to cyanotic attacks. He began to vomit a few days after birth. Vomiting persisted, and at the age of 5 months a barium swallow was performed, which showed free regurgitation at the lower end of the oesophagus with the patient in the supine position. There was no definite evidence of hiatus hernia on the films. The boy was grossly retarded mentally. The urine contained no phenyl-pyruvic acid. The toxoplasm dye and complement-fixation tests were negative, as was the Wassermann reaction. Sucrosuria was first discovered at the age of 15 months.

Case 3. D.B., a female, was a first child, and was delivered by forceps. At the age of 3 weeks she started to vomit, and this persisted up to the time she was investigated at the age of 2 years. A barium meal then showed a large sliding hiatus hernia. The child was grossly retarded mentally and had a spastic quadriplegia. The urine was negative for phenyl-pyruvic acid. Sucrosuria was noticed at the age of $2 \frac{3}{4}$ years. 